\title{
SIETE INTERROGANTES EN LA HISTORIA DEL PENSAMIENTO'
}

\author{
Miguel Cruz Hernández \\ Universidad Autónoma de Madrid
}

\section{RESUMEN}

En las respuestas a siete preguntas resume el autor lo esencial del pensamiento filosófico y religioso del Islam: Cuándo empieza y acaba la Falsafa (Filosofía); cuál fue la aportación de Avicena; si la religión islámica incluye la unión mística; las dificultades para entender a Ibn Jaldún; si el Islam es otra forma rè'razón.

Palabras clave: Islam, Falsafa, Avicena, Ibn Jaldún

\begin{abstract}
In the answer to seven questions, the author resumes what is essential in the philosophical and religious thought of Islam: When the Falsafa (Philosophy) begins and ends; what was Avicena's contribution; the question whether Islamic religion includes the mystical union; the difficulties to understand $\mathrm{lbn}$ Jaldún; whether Islam is another species of reason.
\end{abstract}

Key words: Islam, Falsafa, Avicena, Ibn Jaldún.

\section{1. ¿PORQUÉ SURGIÓ LA FALSAFA?}

Acostumbrados a la fuerza del hecho, parece natural la asimilación del pensamiento helénico por el Islam. Mas conviene recordar otro evento evidente; el cristianismo, que nació y

1 El presente artículo es el texto base de mi última y modesta lección ordinaria como catedrático emérito de Pensamiento Islámico de la Universidad Autónoma de Madrid impartida en noviembre de 2001. Cuando coincidieron en el almanaque del año 2000 de nuestra era los ochenta de mi vida y los cincuenta de catedrático pensé que debía cesar en mi función académica aun cuando estuviera «tiesecito» de cuerpo y animoso de espíritu. Y aunque la Universidad me diese después la posibilidad de prorrogar aún dos años más mi permanencia en ella, creí que debía mantener mi propósito.

Durante los veinticinco años que he profesado en el Departamento de Árabe e Islam, éste me ha dado ánimos y calor para mi labor docente e investigadora en la que se cuentan las obras que tengo por más logradas de mi trabajo. Gracias, pués, a todos sus miembros y especialmente a quien me llevó a él, el profesor Pedro Martinez Montávez, cuyo ejemplo intelectual y moral tanto me ha ayudado en mi trayectoria tras el tiempo en que hube de simultanear la vida universitaria con la pública.

El tema elegido quiere ser un resumen de lo que he aprendido en cincuenta y siete años de docencia, exposición e investigación del pensammiento excogitado en el mundo islámico. La historia es la exposición lo más apróximada y posible de la realidad social de la que puede deducirse su cómo y porqué. Del cómo discurrió el pensamiento islámico no tengo dudas y a mis libros y artículos me remito. Del porqué ya no estoy tan seguro; lo que he creído saber y los problemas que entraña, lo voy a intentar exponer resumidamente, prescindiendo de toda referencia erudita. 
se desarrolló dentro del mundo romano helenizado, no alcanzó dicha asimilación hasta el siglo XIII y ello mediante la recepción del pensamiento árabe tras su traducción al latín. El Islam, tras su rápida y amplísima difusión, tuvo que desarrollar los saberes religiosos sobre el Alcorán, los hadices o tradiciones, el derecho, la espiritualidad y la teología especulativa; nada de ello suponía que también hubiese de asimilar con rapidez, y diría casi con gula, el pensamiento griego; y ello con conciencia plena, de tal modo que a Platón, Aristóteles y demás pensadores helénicos les llamaron los «filósofos antiguos» y ellos se denominaron los «modernos». Parece como si los pensadores árabes o arabizados hubieran pensado como aquel alpinista al que preguntaron porqué escalaba la alta montaña, «porque estaba alli», repondió. ¿Es porque estaba allí, recien traducida al siríaco, por lo que fué retraducida al árabe y al Kindī y al-Fārābī se atrevieron tan rápida y arduamente con la montaña de la aporética, dialéctica y temática de la filosofía griega? Puede ser. Si hemos de aceptar alguna de las anecdotas que refieren los historiadores árabes, me inclinaría por la de la enfermedad de al-Manșūr, segundo califa 'abbāsī, que enfermó de dispepsia el año 765 , no encontrándose ningún médico musulmán que pudiera poner remedio a su enfermedad. Entonces se hizo venir de la ciudad de Gondaysāpōr a un médico nestoriano llamado Ŷyrŷis b. Ŷurŷis que le curó de su dolencia. El califa le habría preguntado acerca del origen de sus conocimientos y $\hat{Y}$ urŷis se habría referido a los sabios de la antiguedad, ordenando al-Manșūr que las obras de aquellos fueran traducidas al árabe. Pero las traducciones debieron empezar en Bayt al-Hikma, fundada en Bagdad por al-Ma'mūn el 832 y dirigida por Yahyà b. Māsuya; y no comenzaron precisamente por la medicina.

Más de uno ha atribuido el interés de al-Ma'mūn a su deseo de oponer las doctrinas de los griegos a la de la Mu'tazila, pero ¿cómo sabía que los «antiguos» pensaban de modo tal que resultaba eficaz frente a la ideologia mu'tazilī? En todo caso el resultado no fué acorde con los deseos, pues la Mu'tazila siguió existiendo varios siglos más y la Falsafa no resultó menos peligrosa que aquella. Tras tantos años de estudiarlo y pensarlo, creo que este es un grande, fundamental y primario problema; una muy dichosa y aventurada ocasión, pero corta y limitada, pues no sobrepasó el siglo XII de nuestra era y, a la postre, sirvió más a la escolástica latino cristiana y a sus consecuencias históricas, que a la posterioridad del pensamiento islámico. Aportación universal del mundo del Islam que éste no aprovechó después en beneficio propio.

\section{2. ¿AVICENA ES SÓLO UN «FAYLASŪF» COMO LOS OTROS?}

Acostumbramos a leer la dialectica de la Falsafa como una línea de Oriente a Occidente: en Oriente vivieron y pensaron al-Kindī, al-Fārābī y Avicena; en Occidente, Avempace, Ibn Tufayl y Averroes. Pero dialécticamente la línea discursiva positiva fué al-Fārābī, Avempace y Averroes. Al-Kindī, el filósofo de los árabes, como fue llamado, es un excepcional precursor y Avicena un promontorio sin par. Si prescindimos del uso dialectico de Avicena en las madrazas islámicas, conviene decir que fue ignorado por Avempace, explotado parcial y partisanamente por Ibn Tufayl y criticado con dureza, con razón y sin ella, por Averroes. Se le recordó siempre, hasta hoy, más como médico que como pensador filosofico, y se presume de su obra filosófica sin tasa ni medida, sin atreverse a imaginar lo que hoy sería su herencia si la Falsafa no hubiera perecido con la desaparición de Averroes. Esta muerte es el siguiente gran problema fundamentel del pensamiento islámico, muy traido y llevado por los investigadores, pero inextricable cuando se le trata con respeto científico; pero antes queda la situación sui generis de Avicena.

Excelente dominador de la lengua árabe, Avicena fue un iraní de raza, lengua y religión. Escribe en árabe y persa; sirvió siempre a los príncipes iraníes y escapó más de una vez del rabioso sunni Mahmūud al-Gaznawī. No hay modo de enclasar su obra en las pautas sunníes; tenerlo por tal por el sólo hecho de ser jurista hanafī, prescindiendo del resto de su vida y su obra, es un simple sofisma; la parte por el todo. Puede ser un šî́ī imāmī muy peculiar, y no 


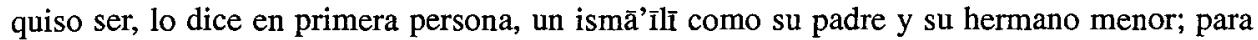
colmo, su discípulo preferido Bahmanyar b. Kìya, fue un mazdeo. Conoció a fondo a Aristóteles interpretándolo a su manera y queriendo cargar su peculiar interpretación a al-Fārābĩ ya que cuenta que leyó la Metafísica del Estagirita cuarenta veces, ya sería menos, sin conseguir entenderlo hasta que se tropezó con el librero que le vendió el libro de al-Fārābī; pero da la casualidad que el texto de al-Fārābī no está en la línea de la interpretación aviceniana. Si esto fuera poco de pronto nos sorprende con escritos, como los dos últimos capítulos de los Išārāt o las «historias» esotéricas de Hayy b. Yaqzān o la del Pájaro. Es casi inconcebible como pudo escribir obra tan grande y variada, pese a sus huidas, su servicio a los príncipes samānies y būyíes, sus aventuras como visir, que lo fue dos veces y una acabó en la carcel, y sus juergas, al decir de su biógrafo casi diarias y tras terminar sus clases. Su fama nunca desapareció en el Islam; su provecho fue una tentación y un servicio para la escolastica latino cristiana, pero Averroes nunca lo vió como un puro faylasūf y lo acusó de mezclar filosofía e ideología religiosa.

\section{3. ¿PORQUÉ TERMINÓ LA FALSAFA?}

Como antes he dicho, un pensamiento tan rico y novedoso en su tiempo como la Falsafa se clausura en el último mes del año 1198 con la muerte de Averroes. También éste dió sus frutos aporéticos, temáticos y dialécticos en el pensamiento latino cristiano de la segunda mitad del siglo XIII y a lo largo de todo el XIV. Fue una nueva cumbre del saber filosófico y el mejor entendedor de Aristóteles que hubo en el mundo hasta el siglo XVIII. Como en las Vidas paralelas de Plutarco, Averroes es el contrapunto respectivo de Avicena, pues como éste, también fue médico; como jurista llegó a cadí mayor de Sevilla y Córdoba, a lo más que un alfaquí y ulema podia aspirar en su tiempo. Para que nada falte, escribió obras como el Tahäfut al-Ta$h a \overline{f u t}$, el Fasl y el Kašf, singulares en el Islam y muy diferentes de sus a veces triples exposiciones de Aristóteles. Esto último no es tan contradictorio: se trata de dos empresas sobre planos dialécticos diferentes. Lo que si lo es fue que tras él nadie más lo intentase, y los que en el Islam desde mediado el siglo XIX y hasta hoy lo han intentado tuvieron y tienen dificultades sin cuento. Y lo más grave: tras Averroes la Falsafa se acabó. Yo he querido encontrar una explicación: la sociedad almohade era incompatible con el desarrollo posterior de la filosofía de Averroes. Bueno, y ¿cómo es que esa sociedad fue compatible con el orto y brillo de Averroes? Quede aquí, pues, este difícil problema.

\section{4. ¿UNA ESPIRITUALIDAD SIN AMOR?}

Una religión es muchas cosas; el no saberlo conduce a las estupideces que suelen oírse hoy. Entre otras más terrenas, es una cosmovisión y una espiritualidad. Se sea agnóstico o creyente no se puede negar la realidad de la religación espiritual. Dicho en caricatura: es más fácil negar a Dios que a Ibn 'Arabī o a Santa Teresa. ¿La espiritualidad fue connatural con el Islam? Algunos piensan que no. El Dios del Alcorán siempre es llamado, con reiteración superabundante, clemente y misericordioso, pero en su esencia no entra la procesion $a b$ intra del amor con Hijo alguno de su propia esencia. El creyente puede aspirar a unirse más y más con Dios, pero alcanzarlo no depende de uno mismo sino de la efusión divina. El hecho es que los místicos islámicos entendieron como real la efusión divina y ello con rapidez y profundidad sin par. Al-Hallāŷ aparece casi a la vuelta de la esquina; si no se escandaliza nadie, diré que es un místico libertario, que terminó arrojando el hábito, la jirka șūfĩ y prescindiendo de la tarīqa, la hermandad cofrade, para predicar la unificación extática con Dios en pleno zoco de Bagdad y acabar crucificado. Las profundidades abisales de Ibn 'Arabi preceden tres siglos a los delinquios amorosos de San Juan de la Cruz. En este caso, dada la espiritualidad șūfī, no hubo 
corte definitivo; šādilies y alumbrados penetran en el siglo XVI y los primeros nunca se extinguieron del todo. Para don Miguel Asín algo de ello debió tocar con tacto impalpable los arribes de San Juan y Santa Teresa. Yo sólo creo en los paralelismos; mas con esto solo, quien da primero da dos veces, y que ello fuera así es un problema más. De cualquier modo no me parece válido preferir el Dios de los ulemas al Dios de los sufíes.

\section{5. ¿PORQUÉ NO SE ENTENDIÓ A IBN JALDŪN?}

Ibn Jaldūn es un historiador sin par, y no por su extenso Kitāb al 'Ibār, una historia de la humanidad, sino por el monumental prólogo que la precede, que como a tal llamó Muqaddima. Su experiencia fue limitada: gran parte del Magreb, algo de al-Andalus y un vistazo a la Sevilla cristiana; su experiencia egipcia fue posterior a su obra. Su mentalidad brillante está condicionada por la de hijo de emigrantes forzados; pero el resultado fue excepcional: el segundo intento de una sociología islámica (el primero fue el de Averroes en su Exposición de la República), y la primera filosofía de la historia, pues La Ciudad de Dios de San Agustin es en realidad una teología de la historia.

También aquí surge el problema: el Islam tuvo a Ibn Jaldūn por sabio e historiador, pero no advirtió su calibre sociológico y su filosofía de la historia, y el Occidente no le conoció hasta el siglo XIX, después de Hegel, Marx y Comte. A partir de entonces Ibn Jaldūn ha cosechado cuantos elogios eran menester y más; digo más por habersele rotulado como «precursor» en uno y otro mundos y habersele escolastizado por la sociología árabe, tanto que, salvo muy honrosas excepciones, se ha llegado a pensar, escribir y enseñar que el mundo árabe solo se puede explicar desde la sociología del genial pensador norteafricano. ¿Y porqué todo ello no fué visto antes? Si se le tenía por sabio e historiador ¿porqué nadie advirtió lo que explica con tanta reiteración en la extensa Muqaddima?, o lo de sabio e historiador son meros epítetos o no se había leído de verdad su obra; les pareció tan natural lo que decía de los tipos de vida y de los modos de producción de cada uno de ellos que no repararon en su sentido, o ¿se habría impuesto la prudente medida del «lejos de nosotros la nefasta manía de pensar»?

\section{6. ¿ENCUENTRO O DESENCUENTRO?}

Desde la segunda mitad del siglo XIX, los estudiosos del mundo islámico y más concretamente los del árabe, se encontraron con el pensamiento europeo moderno: positivismo, evolucionismo, historicismo, personalismo, existencialismo y marxismo. El encuentro personal casi siempre resultó positivo; el social ha sido casi prácticamente nulo, más aún: ha sido de un gran desencuentro. Pese al valioso esfuerzo de numerosos pensadores árabes, su obra ha tenido relativamente más eco en Occidente que en el mundo islámico. El problema estuvo en su coincidencia inicial con la salafiya, la vuelta a los orígenes y la nahda o renovación y después con la interpretación integriata de dichos movimientos. Confieso que la exposición compendiada de este problema me ha costado más años y esfuerzos que el estudio del resto del pensamiento en el mundo islámico. Tras de ello, creo que este problema se levanta sobre dos inquietantes pilares: la base no secularizada del mundo del Islam y la no vigencia social de unos signos de identidad diferentes de los peculiarmente islámicos. Recuerdese que el fracaso del nacionalismo árabe reside en su lucha frente a dos arraigadas realidades sociales: la común islámica y la particular de cada nacionalismo regional, tan evidente en el intento, tantas veces incomprendido, de Gamāl 'Abd al-Nāsir. No se han dado, pues, las condiciones sociales suficientes para que la introducción de las corrientes del pensamiento occidental confluyeran y se realizaran en un pensamiento islámico contemporáneo con vigencia social suficiente y duradera, ni aún en el caso del marxismo, pese a su mayor eco político y a la brillante interpreta- 
ción social de la historia y la filosofía islámicas realizadas por Muruwwa. Que este muriese asesinado en la inextricable guerra civil libanesa y que otros pensadores pasen casi inadvertidos, es señal de referida situación, ¿o es que allá se piensa de otra manera?

\section{7. ¿EL PENSAR ISLÁMICO ES OTRA FORMA DE RAZÓN?}

Y dejando algunos otros problemas que me han preocupado, como el del telón de acero entre el pensamiento sunnī y el šì'î, ¿porqué Mōllà Sadra no fue aprovechado por los sunníes?, el del punto anterior me ha hecho preguntarme, ¿es que acaso el pensar islámico es otra forma de razón? ¿Habrá que ampliar el título de uno de los volúmenes de la excepcional obra de Ŷābirī, al-'Aql al-'arabī, la razón árabe, a todo el mundo del Islam?

Para simplificar con un ejemplo: cuando familiares, amigos o alumnos me han preguntado con que ánimo debían viajar al mundo islámico y más concretamente al árabe, siempre les he dicho: «es otro mundo bien que con los mismos problemas que el nuestro». Si su entendimiento social fuese tambien otro radicalmente diferente, bien poco pudieramos comprender.

Kant concibió la razón como pura y práctica; del paso de la estricta razón pura a la práctica habia una razón pura práctica. Ŷăbirĩ piensa que hay una razón pura práctica árabe, que antes, en su disputa con Hasan Hanafi, era el «modelo occidental, Averroes» frente al modelo oriental Avicena. Se trataría no de una razón esencialmente otra, sino una matización por el modo de ser árabe. ¿Seria asi tambien en el caso del Islam, o éste sería el constitutivo formal de tal modo de ser y pensar? Ciertas confusas ideologías, en el fondo justificadoras de modos sociales incompatibles con la concepción humanísta de la sociedad, responden afirmativamente a la anterior interrogación; pero, a mi entender, deforman a la vez la auténtica realidad de la religiosidad islámica y el sentido de la racionalidad humana. La filosofía es la investigación racional de la esencia de las cosas y de los actos de los hombres.

Por muy modesto filósofo que se sea, no me conformo con el ignoramus et ignorabimus, más aún, si fuera fruto de una esquizofrenia social que admite y hace suyas la ciencia práxica, la tecnificación y la omnisciencia diaria de los mass media, y rechaza las bases personales de la igualdad y libertad sociales. Asi lo ven algunos y se repite mucho estos días. Pero tal visión es contradictoria con la idea misma del significado del ser hombre. Por esto, no comparto tan estrechas andaderas y me gusta caminar con los problemas y las contradicciones a cuestas. Se trata de otro mundo que matiza su razón y que sólo podrá entenderse, antes o despues, desde la común y universal razón humana.

Miguel Cruz Hernández

Catedrático Emérito de Pensamiento Islámico

Universidad Autónoma de Madrid Francisco Gervás, $9,8^{\circ}$ C. 28020 Madrid 